\title{
THE PROVISION OF LEGAL SERVICES TO GOVERNMENT
}

\author{
Sir Geoffrey Palmer
}

This article was presented as a lecture on "Capital Law School Day" organised by the New Zealand Institute of Advanced Legal Studies to mark the occasion of the centenary of the Faculty of Law, Victoria University of Wellington in 1999

On occasions like these it is appropriate to reflect on legal education. On that subject I will say a little at the beginning, but it will be of a personal nature. The profession of law has so many facets now that it is hard to bring them together in a coherent whole. It may not be possible. I will not try. Instead I will offer you some observations based on experience. And it is experience, as Oliver Wendell Homes Jnr told us, that has been the life of the law.

Those of us who were fortunate enough to graduate from this University in the 1960s received a sound legal education. In those days, every subject in the law degree itself was compulsory. There was much to be said for that. For example, had international law not been compulsory then I may not have taken it and my future career would have been considerably handicapped, although there was no way I could have known that then. Indeed, without it, I could never have served as an ad hoc judge in the International Court of Justice. There is no way students who study today can know what they will do in the 40 years of professional life that lie ahead of them after they leave the halls of the academy.

The Law Faculty at Victoria never attempted to teach the content of the law as the prime emphasis of instruction. Had it done so, it would have been a barren and rather useless education. Almost all the law that was on the books when I arrived at this Law School in 1960 has been completely overturned, transformed, developed or changed. The prime pedagogical aim was training in what I call legal method. But it was also necessary for students to be introduced to the culture of the law, especially legal history.

* Honorary Lecturer, Victoria University of Wellington; Partner, Chen \& Palmer, Barristers and Solicitors, Public Law Specialists. 
It was not so fashionable in those days for students to do degrees in other subjects as it is now. In an almost complete reversal of the present trend, most students then did an LLB alone. Furthermore, many students became part-time students after one or two years' fulltime study. And while that tendency certainly made it difficult for proper levels of academic achievement to be attained throughout the degree, it did give the students the advantage of being introduced to practical legal matters within an office at the same time as they were studying the theoretical framework.

When I see the accomplished young graduates of today who arrive in a law office after finishing their law degree as well as another degree, and doing their Professionals, I have cause to consider how lucky I was to be exposed to both strands of the law, more or less simultaneously. I am not sure we have cracked the practical problems of legal education in the current arrangements, although I do not favour returning to the old system.

I remember one Faculty member, Dr B D Inglis, as he then was, telling me when I was the editor of Salient that it was time I went into a law office and stopped being a full-time student. I was then in my fourth year of full-time study. I heeded his advice and it was good advice. And it was he who later encouraged me to study in the United States; an experience that changed my life so considerably I have not yet recovered from it. I arrived in Wellington in 1960 determined to return to Nelson as a solicitor. I have not yet managed to accomplish that goal. And probably I never will. I cannot do the sort of law they do there.

Looking back on my own intellectual development, such as it was, I owe as much to the School of Political Science and Public Administration of this University, as it was then known, as I do to the Faculty of Law. Doing a BA in Political Science was important to me. In particular, reading political philosophy for three years provided a framework of conceptual thinking about the state that I find invaluable still. Indeed, when I returned to Victoria to lecture after my first sojourn in the United States, I lectured in Political Science rather than Law. I favour making the law degree a three-year post-graduate degree. Exposure to other disciplines is essential and enhances the legal skills.

I must be about the only academic at Victoria University who was a lecturer in Political Science and later a Professor of Law. I am also probably the only Prime Minister of New Zealand who has emigrated to the United States twice in his lifetime.

I mentioned Salient. My interest in student journalism flowed from my family background in journalism and the fact that during the University vacations I used to work as a newspaper reporter. I almost left the law shortly before graduation to join the New Zealand Press Association, where my daughter now works as a filing editor.

So by the time I graduated from Victoria University in the mid-1960s, the main intellectual interests of my life had been settled. They were journalism, politics and the 
law. They all remain central to my interests. Indeed, starting a public law firm in New Zealand with Mai Chen - the first such firm in either New Zealand or Australia - has provided me with an opportunity to further interests in all three of these areas of activity. Public law involves them all.

Six years as a Minister of the Crown was in itself a fascinating legal education, and it was that experience from the inside that led me to the conviction that the legal profession was not providing the sorts of services that were required in the changing New Zealand constitutional environment. It became clear to me that most members of the legal profession do not know how government works. Many of the established legal firms advised us against setting up such an enterprise. They said it was quite impossible to make a living out of public law.

We were sufficiently bold to disregard this advice, and nearly five years ago started the specialist public law firm of Chen \& Palmer. Now many of the major law firms are providing public law units within them. Imitation is the sincerest form of flattery.

Chen \& Palmer is perhaps the only law firm in New Zealand that has ever been founded on the basis of a vision that was articulated in published Law Review articles prior to it being implemented. It was the Victoria University of Wellington Law Review and the article was entitled "The New Public Law: Its Province and Function" ${ }^{1}$ - that, in itself, suggests, I think, the eternal utility of thought, analysis and reflection; the values that a university holds dear.

What lawyers do has changed drastically in my generation. It promises to change even faster in the future. It is only the critical application of new ideas and the courage to change that allows progress to be made.

The New Zealand legal environment is, in many ways, a hotch-potch of intellectual traditions which sit awkwardly with one another. My way of thinking about law is American. It is American in its jurisprudential orientation: American realism. And it is American in its approach to the method of treating law and politics as dynamically interrelated. It is most distinctly non-Diceyan.

All this is a rather long way of getting to the matter that I want to discuss. It is a matter of law reform. But it is not quite the same sort of law reform as usual. It is to do with the organisation of legal services within the New Zealand Government.

1 Geoffrey Palmer "The New Public Law: Its Province and Function" (1991) 22 VUWLR 1. 
I take as my text, as so often I have in my various activities in the law both in Government and out of it, from Karl Marx. He said "[t]he philosophers have only interpreted the world, in various ways; the point, however, is to change it". ${ }^{2}$

There is much in the adage "once an academic always an academic". I still teach administrative law at this University with my colleague Mai Chen. Bill Atkin prevailed on me to write an article for the Centennial Issue of the Victoria University of Wellington Law Review. So I took the opportunity when I was teaching comparative constitutional law in the United States in March and April to write an article that had been stimulated by some experiences I had in practice. It is called "Deficiencies in New Zealand Delegated Legislation". ${ }^{3}$ In the best traditions of academia, one piece of research always leads to another.

I will not rehearse the deficiencies of delegated legislation in New Zealand, although I regard them as very serious. Let me just read the last two paragraphs of the article to you: 4

It is not the thesis of this article that regulation is unnecessary or that regulatory interventions are by definition undesirable. Rather, such interventions should be more carefully judged than they are in New Zealand. The New Zealand government system still lacks both an intellectual and practical framework for arriving at those judgments within the Executive Government system. But there are dangers in entrusting too much power to public agencies. Recent developments in New Zealand show that we are heading in that direction. It is a tendency that has crept up on us incrementally. The coherence of our legal system is threatened by it.

Better machinery needs to be devised within the Executive Government to ensure that the collective interests of the Government are being served by both proposed regulations and rules. There is a real danger that officials and drafters in departments and agencies capture both the process and the agenda. The issues here deserve serious policy attention, but there is no government agency with the responsibility and the resource to do anything about it. Better advice systems are probably the most urgent need.

These recommendations indicate that we have not made sufficient progress from the time of the Rt Hon Lord Hewart of Bury, the critic of delegated legislation in his controversial work The New Despotism. ${ }^{5}$

2 Karl Marx The German Ideology: including Theses on Feverbach and Introduction to the Critique of Political Economy (Prometheus Books, Amherst (NY), 1998) no 11.

3 Geoffrey Palmer "Deficiencies in New Zealand Delegated Legislation" (1999) 30 VUWLR 1.

4 Palmer, above n 3, 31. 
The most difficult challenge for any government is the achievement of co-ordination and integration of its policies. The pervasive character of overall legislative and constitutional policy makes the task of integration still more difficult.

I found that some measure of co-ordination could be achieved within the legal area of government by holding the portfolios of Justice, Attorney-General and Leader of the House. Being Deputy Prime Minister was also a help.

If one examines the law enterprise within government in terms of the modern language of outputs, one cannot find a principled distinction between litigation, legal advice and opinion writing, and legislation (whether delegated legislation or Act of Parliament). There is also such a thing as legal policy within the Government which crosses all the boundaries of departments. It is only the New Zealand Government as a whole that is concerned with the sovereignty of the New Zealand State. It is the New Zealand Government that has the prime responsibility for the delivery of the rule of law in a democratic society. It is the New Zealand Government that has the prime responsibility for shaping the constitution of the country and adhering to its constitutional practices.

To my way of thinking the manner in which the legal services are delivered to the Government is deficient.

One of the prime deficiencies is structural. There is a Balkanisation of the legal services within the New Zealand Government. Crown Law Office provides legal advice and litigation. It has some of the constitutional functions, but not all of them.

Each department has its own solicitors providing advice. By the time a problem reaches the Crown Law Office, it is sometimes too late to put the matter right. Proper and proactive use of legal advice would see many of the problems that beset government nipped in the bud before they began, if the legal advice was of the appropriate standard and delivered at the appropriate time. Often the advice should be about the standards to be applied in legislative or regulatory proposals. Instrument choice for public entities is another area where there needs to be proper advice.

Then there is the Parliamentary Counsel Office. They are responsible for drafting the Acts and Regulations. They live in an agency of their own and they are not therefore exposed to the litigation risks run by the Government in the same way that the Crown Law Office is. They are frequently not involved with the policy development process which is a pity because they could add value.

5 Lord Hewart of Bury The New Despotism (Benn, London, 1929). 
The Ministry of Justice has been completely restructured in recent years and is not as big and powerful as it was. It has lost many of its responsibilities to the Department of Corrections and the Department for Courts. It has also had many of its statutes transferred to the Ministry of Commerce for administrative purposes.

The old law reform division of the Department of Justice has gone and while that development may have created something of a vacuum, it has also provided the opportunity to make what could be regarded as a big and useful reform.

None of this is new. Nor is it limited to New Zealand. In a recent paper, Patricia Wald, a judge of the United States Circuit Court of Appeals for the District of Columbia Circuit, noted her experiences of seeing government agencies on opposing sides of disputes, of the Government filing an amicus brief in litigation involving one of its own agencies, and of the Congress representing itself directly through the Office of Senate Legal Counsel or indirectly through the actions of an Independent Counsel. ${ }^{6}$

Notwithstanding that our problems are less severe than that, I was worried about it as a Minister. Indeed, I set up a committee to provide a report on it. In August 1986 the State Services Commission provided to me as Attorney-General A Review of Government Legal Services. As I said in the foreword: ${ }^{7}$

This review is overdue. The government legal services in New Zealand have not previously been subjected to systematic study. They have grown in an unco-ordinated and fragmentary manner. Over recent years there has been growing concern on the part of government lawyers and those they serve that they are not geared to meet the increasing demands being made on them.

The report carried out by Gordon Orr and David Bradshaw is worth re-reading. I believe its fundamental finding remains sound. It was:

[t]he principal cause of present weaknesses in the New Zealand Government legal service is the almost total absence of any co-ordination of those services. Unless this major defect is remedied the prospects of significant improvement appear slight.

It is interesting to note that the Orr Report considered four broad possibilities in determining how New Zealand's government legal services might be better provided. These were:

6 Patricia M Wald "'For the United States': Government Lawyers in Court" (1998) 61 Law \& Contemporary Problems 107, 127.

7 G S Orr \& D J Bradshaw A Review of Government Legal Services (State Services Commission, Wellington, 1986) 1. 
- $\quad$ Retain the present framework with improvements where desirable.

- Establish several legal units each of which would serve several departments having related interests and responsibilities.

- Establish a new centralised law department incorporating the functions of the Solicitor-General, the Crown Law Office, and the law reform division of the Department of Justice, with departmental office solicitors and their staff either:

(i) All physically located in one central office or, where appropriate, in regional offices; or

(ii) With secondments to the head office of departments and, where appropriate, to district offices of departments.

- Restructure the Crown Law Office by redefining the duties and responsibilities of the Solicitor-General and by incorporating Crown Counsel in an Attorney-General's Department under a new permanent head with overall responsibility to the Attorney-General for co-ordinating the government legal services and ensuring their efficiency.

The report chose the fourth option. The situation we face now is very different, particularly since the law reform division of the old Department of Justice is no more. Incidentally, the report never reached Cabinet and was, I believe, overtaken in all the activity surrounding the State sector reforms.

The report recommended that the Attorney-General's department should have three main divisions - the Crown Law Office, the Legal Services Directorate and the Regulations Branch.

There were a series of recommendations about legal advice in Departments as well. Following the Australian model, the Attorney-General's Department would keep jurisdiction over those legal advisers in the various Ministries, except for the legal advisers in the Ministry of Foreign Affairs and Trade.

One recommendation of current interest is number 43:

the Directorate of Legal Services should undertake a review of the present role of office

solicitors in their Department's legislative programme and make recommendations to permanent heads as to any changes which should be made.

It also said that early consideration should be given to the introduction of a modern management structure in the Office of Parliamentary Counsel.

The report was prepared before the great changes in the State sector produced by the State Sector Act 1988, the State-Owned Enterprises Act 1986, and the Public Finance Act 
1989. No doubt many of the details are no longer applicable. But the overall problems remain. The report is not a bad place to start addressing them.

There are serious policy failures from a legal point of view within the New Zealand Government. Currently these are not being addressed because no-one has the responsibility for addressing them. That has been particularly the case in relation to the development of deemed regulations which is a matter the Regulations Review Committee has in front of it now.

The lack of co-ordination has probably been exacerbated by the changes to the State sector. The absence of an agreed set of standards or set of procedures across various departments relating to legal matters must lead to many instances where the wheel is reinvented. The Crown can often receive different legal advice on similar problems. There must be a good deal of duplication.

There can also be a failure on the part of legal practitioners to recognise, and respond to the particular challenges of involvement in public policy. Professor Peter Schuck of Yale University, a former member of the Office of the Assistant Secretary for Planning and Evaluation, noted: ${ }^{8}$

many government lawyers make a less valuable contribution to the policymaking process than their natural talents, acquired skills, industry, and prominence in public life would lead us to hope and expect.

These challenges to the legal skills of many practitioners are in addition to the particular ethical and constitutional obligations of practitioners acting for government. ${ }^{9}$ Of these, the United States Supreme Court has said: "[t]he United States Attorney is the representative not of an ordinary party to a controversy, but of a sovereignty whose obligation to govern impartially is as compelling as its obligation to govern at all". ${ }^{10}$

What is to be done?

I would bring the following disparate groups under one roof in one department. They are:

- $\quad$ The Crown Law Office.

- $\quad$ The Ministry of Justice.

8 Peter Schuck "Lawyers and Policymakers in Government" (1998) 61 Law \& Contemporary Problems 7, 10.

9 For a recent comment see B Selway "The Duties of Lawyers Acting for Government" (1999) 10 Public LR 114.

10 Berger v United States (1935) 295 US 78, 88. 
- The Office of Treaty Settlements. (There is a case for a department to deal with Treaty issues alone.)

- Parliamentary Counsel Office.

I would call it the Law Department. I would make it responsible for providing legal advice to departments. It should be given control functions in respect to the legal activities of other departments.

By having one government legal service covering both litigation legal advice and legislation I would expect to be able to achieve synergies and improvements that are not now available. I would leave the Foreign Affairs legal advice section out of the structure, although the case for doing so is not watertight given the greater realisation these days of the degree to which treaties impinge on New Zealand's domestic law.

The main advantage of the suggested structure is that it will ensure that the prime difficulty is overcome. At the moment no one in the government legal service has authority or responsibility for its efficiency and effectiveness.

Structural change is seldom any use if engaged in for its own sake. The suggestions I am making here are born of an intellectual conviction backed up by practical experience. The problems of the public law system in New Zealand are organic and they require an organic solution. Legislation cannot be fenced off from litigation. Negotiation of Treaty settlements cannot be fenced off from liability advice in respect to Maori litigation which is a rapidly expanding field. The interconnected character of government legal practice has been recognised by United States courts, which censured government litigants where the possibility of resolving litigation by changes to policy had not been disclosed. ${ }^{11}$

A strategic approach to the Government's legal problems will lead to a quite different set of coherent solutions to legal problems that arise within government. These ideas have been etched in charcoal outline only. No doubt they will be greatly resisted in some quarters. But I think they ought to happen.

The point of the proposal discussed in this paper is that Ministers need and deserve better and more comprehensive strategic advice than they can obtain from the existing disparate structures. There are too many areas within the New Zealand Government where fundamental questions are never asked and no one has the responsibility to ask

11 Gray Panthers v Schweiker (1983) 716 F 2d 33 (DC Cir): "We have previously emphasised that counsel are required to inform the courts of outside developments that might affect the outcome of litigation. And counsel for the government, no less than their colleagues in the private sector, are bound by the same obligations to the court. There is, indeed, much to suggest that government counsel have a higher duty to uphold because their client is not only the agency they represent but also the public at large." 
them. Prime amongst them is the issue that has been around now for many years: "Why is this law necessary? Can we do without it? If we need it, what is the best means of achieving the policy goal? If regulation is necessary, what is the appropriate instrument to choose to accomplish it and what are the costs and benefits of it?". We have been slow indeed to take up law and economics analysis in New Zealand as a means of looking at regulatory policy. But much value is to be gained from it.

To my mind, one of the most interesting of the current problems facing the Government relates to Crown entities. There are well advertised shortcomings in the accountability systems for these various disparate bodies. The whole area needs to be thoroughly and rigorously reviewed. To my way of thinking, many Crown entities should be abolished - a new QANGO hunt. Others should be returned as departments of State. Others probably deserve a separate government regime of their own, for example all the school committees. For the rest, it should be possible to devise a generic statute along the lines of the State-Owned Enterprises Act that provides a coherent system of governance with proper public law accountabilities.

A tell-tale sign of what is wrong with the public law system in New Zealand and the advice systems within it is to be found here. Treasury and the State Services Commission are doing the work that the Government has urgently ordered up on reforming the Crown entities. That illustrates exactly what I am on about here. The problems are structural, they are legal, they are constitutional, and they are legislative. The agencies providing the advice do not have expertise in these areas.

The issues involve the appropriate instrument choice in many cases. Surely the Government is entitled to have within it an agency capable of advising on those issues in a comprehensive, competent and strategic manner.

In 1992, in the wake of the Fitzgerald inquiry, the Queensland Government sought to introduce procedural safeguards into the legislative process. The Office of the Queensland Parliamentary Counsel was established, together with a Parliamentary Committee on Legislation, to advise on whether new legislation was consistent with principles including the requirements of natural justice, basic requirements of human rights and sound legislative practice. It was also entrusted with responsibility for clarity and precision in legislative drafting. ${ }^{12}$

But the role of the Office is limited. Its role comes after policy decisions have been made and is, in any event, essentially recommendatory: it has no power to oppose inconsistent new legislation or to overturn existing statutes. While the Office has had some

12 Legislative Standards Act 1992 (QLD) s 4. 
success in improving the quality of drafting - in itself a significant accomplishment - it appears ill-equipped to oppose the contrary wishes of government. The Office has already been deprived of its function of preparing a cost-benefit impact analysis of subordinate legislation. ${ }^{13}$

Perhaps the only way we will achieve the appropriate constitutional and legal standards within government is to adopt a written constitution in the form of a higher law. The New Zealand Bill of Rights Act 1990 achieves some of the Queensland goals in the New Zealand context but not enough of them. In broad terms, a constitution brings with it a degree of prominence, permanence and rhetorical strength that a code of legislative practice is unlikely ever to approach. More specifically, a written constitution entrusts ultimate responsibility for governmental standards with the courts, rather than with a bureaucratic agency of necessary vulnerability.

I have long believed that New Zealand courts should have the power to declare statutes unconstitutional. I did not, however, believe that in 1968 when I published, on the encouragement of and under the editorship of Sir Kenneth Keith, an essay condemning such a move. ${ }^{14}$ But as a Minister I tried to bring it about with the New Zealand Bill of Rights Act 1990. I wanted that legislation entrenched and I still do. That may be the only way ultimately of preventing bad legislation and imposing appropriate legal standards on the government system.

In conclusion, let me remind you of Benjamin Nathan Cardozo's wonderfully evocative defence of judicial review of legislative action in the nature of the judicial process - a book I first read when studying jurisprudence at Victoria University of Wellington under Dr Donald Mathieson QC as he now is: ${ }^{15}$

The utility of an external power restraining the legislative judgment is not to be measured by counting the occasions of its exercise. The great ideals of liberty and equality are preserved against the assaults of opportunism, the expediency of the passing hour, the erosion of small encroachments, the scorn and derision of those who have no patience with general principles, by enshrining them in constitutions, and consecrating to the task of their protection a body of defenders. By conscious or subconscious influence, the presence of this restraining power,

13 Office of the Queensland Parliamentary Counsel Annual Report 1997 - 1998 (Government Printer, Brisbane) 21-22.

14 Geoffrey Palmer "A Bill of Rights for New Zealand?" in K J Keith (ed) Essays on Human Rights (Sweet \& Maxwell, Wellington, 1968) 106.

15 Benjamin Cardozo Nature of the Judicial Process (Yale University Press, New Haven, 1921) 92-93. (See also the wonderful biography by A L Kaufman Cardozo (Harvard University Press, Massachusetts, 1998).) 
aloof in the background, but none the less always in reserve, tends to stabilize and rationalize the legislative judgment, to infuse it with the glow of principle, to hold the standard aloft and visible for those who must run the race and keep the faith.

This Law School is in Wellington, the seat of the New Zealand Government. The levers of power are more accessible here than in any democracy I know. What wonderful things we could achieve if we were properly organised. 
